\title{
Local Wisdom of Religious Tourism in East Java
}

\author{
Putut Handoko \\ Faculty of Letters \\ Dr. Soetomo University \\ Indonesia \\ puh-andaka@yahoo.co.id
}

\author{
Hariyono \\ Faculty of Letters \\ Dr. Soetomo University \\ Indonesia \\ bagushariyono@gmail.com \\ Cahyaningsih Pujimahanani \\ Faculty of Letters \\ Dr. Soetomo University \\ Indonesia \\ thesis.sastra@gmail.com
}

\begin{abstract}
The research deals with local wisdom of religious tourism in East Java. The aim of the study is to preserve Javanese moslem spirituality against material things and radical views. The local wisdoms of Sunan Ampel's cemetery, Sunan Drajat's cemetery, and Sunan Giri's cemetery in East Java are moral teaching such as the ways of righteousness, the ways of Islam, the ways of peacefulness, harmony, good deed, mortality and immortality, the ancestral spirit place, the abode of God, the sacred place, and good relationship with God and men.
\end{abstract}

Keywords—local wisdom; cemetery; tomb

\section{INTRODUCTION}

Recently, the teaching of Islam is blackened with the terrors, including the attacks in Surabaya. The bomb attacks in Surabaya on May $13^{\text {th }}$, 2018 attack the value of religious harmony that becomes a great tradition in Surabaya and East Java. The harmony is related to the local wisdom that is rooted in the teaching of Islam which contains the ways of righteousness and peacefulness, harmony among different faiths, and righteous deeds. The reflections of Islamic teaching as local wisdom can be manifested in cemetery of the Javanese moslem saints, Sunan Ampel, Sunan Drajat, and Sunan Giri.

Local wisdom is defined as values constructed, developed, and preserved by a community that becomes the ways of life of the people [1]. In understanding the definition, the researchers understand that the Javanese moslems in East Java have their pride in maintaining their Islamic values transmitted from one generation to the next ones. By maintaining the local wisdom owned by the Javanese moslems, it is expected that they can live in harmony, because the problems faced in the modern era are the hardship to live in harmony (Na Thalang in [2, p. 177]). The hardship happens after the community moves to adopt the new ideas that threaten the harmony by transforming the radical views that are not rooted in Javanese moslem culture. The respect of elders and moral values is more preferable to material things as stated by Nakorntap (in [2, p. 176]) that the idea is also the manifestation of local wisdom of Javanese moslem community that should be maintained and developed, so that the harmony can be preserved. The local wisdom of Javanese moslem spirituality can be a solution for the future of Islam in Java. By considering the perspective, therefore, the objectives of this research are to describe the local wisdoms of religious tourism such as Sunan Ampel's cemetery, Sunan Drajat's cemetery, and Sunan Giri's cemetery. The researches of Local wisdom have been conducted by some researchers as follows: (1) Archanya Ratana-Ubol and John A. Henschke with their writing, entitled Cultural Learning Processes through Local Wisdom: A Case Study on Adult and Lifelong Learning in Thailand [3], (2) Leo Agung S with his writing entitled The Development of Local Wisdom-Based Social Science Learning Model with Bengawan Solo as the Learning Source [4], (3) Purwati Anggraini and Tuti Kusniarti with their writing entitled Character and Local Wisdom-Based Instructional Model of Bahasa Indonesia in Vocational High Schools [5], (4) Weerakul Chaiphar Thongphon Promsaka Na Sakolnakorn and Aree Naipini with their writing entitled Local Wisdom in the Environmental Management of a Community: Analysis of Local Knowledge in Tha Pong Village, Thailand [6], (5) Dahliani, Ispurwono Soemarno, and Purwanita Setijanti entitled Local Wisdom in Built Environment in Globalization Era [7], (6) Dewi, Ika Nurani, Sri Poedjiastoeti and Binar Kurnia Prahani with their writing entitled ELSII Learning Model Based Local Wisdom to Improve Students' Problem Solving Skillas and Scientific Comunication [8], (7) Sudarmin, and Rr. Sri Endang Pujiastuti entitled Scientific Knowledge Based Culture and Local Wisdom in Karimunjawa for Growing Soft Skills Conservation [9], (8) Miss Roikhwanphut Mungmachon with her writing entitled Knowledge and Local Wisdom: Community Treasure [2], (9) Ade Prasetyo with his writing entitled Folklore in EFL: The Local Wisdom Implementation of Indonesian Curriculum [10], (10) Utit Sungkharat, Piboon Doungchan, Chantas Tongchiou and Banlue Tinpang-nga with their writing entitled Local Wisdom: The Development 
Of Community Culture And Production Processes [11], and (11) Putut handoko and Cahyaningsih Pujimahanani entitled Local Wisdom of Folklore in Gresik East Java [12].

Local wisdom can be found through the life of Javanese saints that lived at the early coming of Islam in East Java. The cemeteries of Sunan Amplel, Sunan Drajat and Sunan Giri are studied to reveal the spiritual aspects so that the local wisdom can be preserved. Therefore, the aim of this research is to preserve Javanese moslem spirituality against material things and radical views by valuing the local wisdom the cemeteries of Sunan Ampel, Sunan Drajat, and Sunan Giri. This is a field research project that is done by observing the objects that are identified as the data. The data are taken from the cemeteries of the three Islamic saints, Sunan Ampel (Surabaya), Sunan Drajat (Lamongan), and Sunan Giri (Gresik). The data are collected from the artifacts that are related to the three Islamic saints'cemeteries. The data are also supported by materials, such as the historical book entitled Atlas Wali Songo, Babad Sejarah Madura, Babad Giri Kedathon and Sejarah Regent Soerabaja. The technique of data collection is done by documenting the observed data, and the selected materials, the analysis is done by connecting the aims of this research with the data that are found.

This research discusses local wisdom as other researchers above. However, this research has its originality on the focus of studied local wisdom on the stress on the importance of the role of religion (Islam) in making the social cohesiveness among its members. The mentioned previous studies show that local wisdom which is discussed by the mentioned Thai and Indonesian researchers have different cultural background. Buddhism is the religion of the vast majority of the Thai people, while Islam is the religion of many Indonesians, and the researchers of this research consider that religions play an important role in many parts of Asian people, especially Indonesia where Karel Steenbrink states that Islam has crucial influence in building societies in Indonesia [13, p. 216]. The researchers realize that Islam nowadays becomes the inspiration of misguided people who use Islam for the destruction, in which the researchers think this is not on the path of local wisdom of Islam as described by findings of this research. In short, this research is to fill the gap that Islam that is preached in Java with its local wisdom should be strengthened against the narrow minded teaching of Islam that blackens the values of Islam.

\section{ANALYSIS}

\section{A. Local Wisdom of Sunan Ampel's Cemetery}

\section{1) Sunan Ampel's tomb}

Sunan Ampel passed away and was buried at Sunan Ampel's cemetery. His name was recorded in many historical book such as, Atlas Wali Songo, Babad Sejarah Madura, Babad Giri Kedathon, Babad Tanah Jawi, and Sedjarah Regent Soerabaja [14]. Through the historical books, it is known that he built Ampel Denta Islamic boarding school. As a saint, he taught his students Raden Samudra (Sunan Giri), Lembu peteng (the ruler of Madura, son of king Majapahit), Mbah Sholeh, Mbah Bolong, and the saints. So local wisdom of his tomb is that he taught his students islam, the ways of righteousness, the ways of peacefulness, harmony,and good relationship with God and men. As the first regent of Surabaya, he led his regent with the ways of islam, peacefulness, justness.

\section{2) Lembu Peteng's tomb}

He was the ruler of Madura as stated in Babad Sejarah Madura [15], who wanted to combat Kanjeng Sunan Ngampeldenta. But, being defeated, he became the student of Kanjeng Sunan Ngampeldenta, and died at Sunan Ampel cemetery. The local wisdom is that a person who found the ways of righteouness, Islam, learning Islam until died.

\section{3) Mbah Sholeh's tomb}

Based on myth, Mbah Sholah was first a robber. Being defeated by Kanjeng Sunan Ampel, he became the student of Kanjeng Sunan. Besides, he did clean the mosque.When he died, Kanjeng Sunan asked him and said that mbah sholeh cleaned the mosque well. Mbah Sholeh who had died, backed to live. It happened nine times. The local wisdom is that a person who found the ways of righteousness, Islam and did his job very well.

\section{4) Mbah Bolong's tomb}

One of Kanjeng Sunan Ampel's students was Mbah Bolong.He has a miracle to see a ka'bah from a hole in the wall. The local wisdom is that a person who can see ka'bah from a hole and without going to Maakah.

The local wisdom of Sunan Ampel's tomb, Lembu Peteng's tomb, Mbah sholeh's tomb, and Mbah Bolong's tomb are moral teaching such as the ways of righteousness, the ways of peacefulness, harmony, good deed, and good relationship with God and men.

\section{B. Local wisdom of Sunan Drajat's cemetery}

Sunan Drajat's cemetery consists of Sunan Drajat's tomb, the seven stairs, banyan tree, sapodilla tree, a couple of tamarind tree, sapit urang temple, lotus flower, and hall of the chain.

\section{1) The seven stairs}

Local wisdom of the seven stairs is as follows:

\section{a) The first stair}

The first stair, entering the great door is written memasang resep teasing sasonto (kita selalu membuat senang hati orang lain/ we always make the other happy)

\section{b) The second stair}

The second stair is written laksitaning suko kudu lan waspodo (dalam suasana riang kita harus selalu ingat dan waspada/ in a cheerful atmosphere, we always remember and are vigilant).

\section{c) The third stair}

The third stair is written Laksitaning broto tan nyepto marang pringgo bayaning lampa/ dalam perjalanan untuk mencapai cita cita luhur kita tidak perduli dengan berbagai 
rintangan/ in the journey to achieve the deal of noble, we do not care about various obstacles.

\section{d) The fourth stair}

The fourth stair is written memper harganing ponco driyo/ kita harus menekan hawa nafsu/we should push down carnal desire.

\section{e) The fifth stair}

The fifth stair is written heneng-hening-henung/ dalam keaaan diam kita akan memperoleh keheningan, dan dalam keadaan hening kita akan mnecapai cita cita/ being silence, we will gain silence and a state of silence we will achieve the goal.

\section{f) The sixth stair}

The sixth stair is written mulyo guno ponco waktu/suatu kebahagiaan lahir batin hanya bisa dicapai dengan sholat lima waktu/ an inner-born happiness can only be achieved by fivehour prayers.

\section{g) The seventh stair}

The seventh stair is written menehono teken wong kan wuto/berilah ilmu orang yang buta agar / give the blind knowledge in order to make him clever, menehono mangan marang wong kan luwih/ sejahterahkanlah kehidupan masyarakat yang miskin/welfare the lives of the poor.

\section{2) The banyan tree/beringin tree}

The banyan tree/beringin tree symbolizes that people come to the place with intention.

\section{3) Sapodilla tree/sawo tree}

Sapodilla tree symbolizes that we are always looking for the good things.

\section{4) A couple of tamarind tree/ asem tree}

A couple of tamarind tree symbolizes "smile" meaning a vertical understanding: sincere, trustworthiness, and prostration, and in harmony in relation to others we must be able to create happy atmosphere.

\section{5) Sapit urang temple} ofty.

It symbolizes the journey of living in reaching the ideal of

\section{6) Lotus flower}

It symbolizes life after death, immortality and mortality.

\section{7) Hall of the chain}

It symbolizes the continuity of the Majapahit at that time and also symbolizes the transformation (Hindu-Islam).

The local wisdoms of trees, the seven stairs, temples, and lotus flower at Sunan Drajat's cemetery are moral teaching such as the ways of righteousness, on the ways of Islam, harmony, the good relationship with God and men, good deed, mortality and mortality.

\section{Sunan Giri's cemetery}

Sunan Giri's tomb has been researched by Tantri, Cicilia, Handoko, and Budianto in a paper entitled Perbedaan makna simbolis relief Gunung pada situs makam Sunan Giri dan Situs Makam Sunan Sendang Duwur (The difference of symbolic meaning of Mountain relief as seen in Sunan Giri artifact and Suna Sendang Duwur artefact) [16]. Sunan Giri's cemetery consists of Suan Giri's tomb, Sunan Giri's dome with its relief. Sunan Giri is a historical figure who buried at Sunan Giri's cemetery. That he was a saint, a teacher and a king at Giri's palace is recorded in Babad Giri Kedathon. Sunan Giri spreaded and taught islam to his students. He taught Islam the ways of righteousness, the ways of Islam, harmony, and the good relationship with God and men. The relief in Sunan Giri's dome is the element of monster symbolizing that the bad power does not enter the cemetery. The second is the element of lotus flower symbolizing life after death, immortality ad mortality. The third is the element of mountain relief symbolizing the place of the ancestral spirits, the abode of the gods, and the sacred place.

The local wisdoms of Sunan Giri's tomb, the relief of monster, the relief of lotus, and the relief of mountain are moral teaching such as the ways of righteousness, the ways of Islam, harmony, the good relationship with God and men, mortality and immortality, the ancestral spirit place, the abode of God, and the sacred place.

\section{CONCLUSION}

The local wisdoms of Sunan Ampel's tomb, Lembu Peteng's tomb, Mbah sholeh's tomb, and Mbah Bolong's tomb are moral teaching on the ways of righteousness, the ways of peacefulness, harmony, good deed, and good relationship with God and men.

The local wisdom of trees, the seven stairs, temples, and lotus flower at Sunan Drajat's cemetery are moral teaching on the ways of righteousness, on the ways of Islam, harmony, the good relationship with God and men, good deed, mortality and mortality

The local wisdoms of Sunan Giri's tomb, the relief of monster, the relief of lotus, and the relief of mountain are moral teaching on the ways of righteousness, the ways of Islam, harmony, the good relationship with God and men, mortality and immortality, the ancestral spirit place, the abode of God, and the sacred place.

\section{REFERENCES}

[1] Y. Aprianto, Kearifan Lokal dalam Mewujudkan Pengelolaan sumber daya air yang berkelanjutan [Local wisdom in creating sustainable water resource management]. Bogor: IPB, 2008.

[2] M. R. Mungmachon, "Knowledge and Local Wisdom: Community Treasure,” Int. J. of Human. and Soc. Sci., vol. 2, no. 13, July 2012.

[3] A. Ratana-Ubol and J. A. Henschke, "Cultural Learning Processes through Local Wisdom: A Case Study on Adult and Lifelong Learning in Thailand,” Int. J. of Adul. Vocation. Edu. and Technol., vol. 6, no. 2, pp. 41-60, April-June 2015. 
[4] L. Agung S, "The Development of Local Wisdom-Based Social Science Learning Model with Bengawan Solo as the Learning Source,” Amer. Int. J. of Soc. Sci., vol. 4, no. 4, August 2015.

[5] P. Anggraini and T. Kusniarti, "Character and Local Wisdom-Based Instructional Model of Bahasa Indonesia in Vocational High Schools,” J. of Edu. and Prac., vol. 8, no. 5, 2017. [Online]. Available: www.iiste.org. ISSN 2222-288X.

[6] W. Chaiphar, T. P. N. Sakolnakorn, and A. Naipinit, "Local Wisdom in the Environmental Management of a Community: Analysis of Local Knowledge in Tha Pong Village, Thailand,” J. of Sustain. Develop., vol. 6, no. 8, 2013.

[7] Dahliani, I. Soemarno, and P. Setijanti, "Local Wisdom in Built Environment in Globalization Era,” Int. J. of Edu. and Res., vol. 3, no. 6, June 2015.

[8] I. N. Dewi, S. Poedjiastoeti, and B. K. Prahani, "ELSII Learning Model Based Local Wisdom to Improve Students' Problem Solving Skillas and Scientific Comunication,” Int. J. of Edu. and Res., vol. 5, no. 1, January 2017.

[9] Sudarmin and R. S. E. Pujiastuti, "Scientific Knowledge Based Culture and Local Wisdom in Karimunjawa for Growing Soft Skills Conservation,” IJSR, vol. 4, no. 9, September 2015.

[10] A. Prasetyo, "Folklore in EFL: The Local Wisdom Implementation of Indonesian Curriculum,” J. of ELT Res., vol.1, no. 2, 2016.
[11] U. Sungkharat, P. Doungchan, C. Tongchiou, and B. Tinpang-nga, "Local Wisdom: The Development of Community Culture and Production Processes in Thailand,” Int. Bus. \& Econ. Res. J., vol. 9, no. 11, November 2010.

[12] P. Handoko and C. Pujimahanani, "Local Wisdom of Folklore in Gresik East Java,” Proceeding: Seminar International Enrichment of Career by Knowledge of Language and Literature V, 2017.

[13] K. Steenbrik, Kawan dalam Pertikaian [Friend in a Dispute]. Bandung: Mizan, 1996.

[14] P. Handoko, “A Historical Value of Sunan Ampel (Raden Rahmad) and Sunan Boto Putih (Lanang Dhangiran) Surabaya,” Proceeding: The 3rd Annual Malang International Peace Comperence (AMIPEC), Malang: Universitas Islam Raden Rahmat (UNIRA), 2017.

[15] P. Handoko, "Babad Sejarah Madura (Kajian Struktur, Fungsi, Nilai Budaya dan Nilai Sejarah) [Madurese Chronicle History (Study of Structure, Function, Culture Values, and History Value)]," Thesis, Surabaya State Univ., 2004.

[16] Tantri, Cicilia, P. Handoko, and S. Budianto, Perbedaan makna simbolis relief Gunung pada situs makam Sunan Giri dan Situs Makam Sunan Sendang Duwur [The difference of symbolic meaning of Mountain relief as seen in Sunan Giri artifact and Suna Sendang Duwur artefact]. DIPA UNITOMO Research, 2013. 